2006

\title{
Dependency by Law: Poverty, Identity, and Welfare Privatization
}

Frank W. Munger

New York Law School, frank.munger@nyls.edu

Follow this and additional works at: http://digitalcommons.nyls.edu/fac_articles_chapters

Part of the Health Law and Policy Commons, Law and Economics Commons, and the Social Welfare Law Commons

\section{Recommended Citation}

13 Ind. J. Global Legal Stud. 391 (2006)

This Article is brought to you for free and open access by the Faculty Scholarship at DigitalCommons@NYLS. It has been accepted for inclusion in Articles \& Chapters by an authorized administrator of DigitalCommons@NYLS. 


\title{
Dependency by Law: \\ Poverty, Identity, and Welfare Privatization*
}

\author{
Frank Munger**
}

\begin{abstract}
Privatization of welfare reflects the political pressure to limit public responsibility for protection of social citizenship. Recent welfare reforms incorporate three classic market-like privatization mechanisms - contracting out services, forcing allocation of a limited pool of benefits, and deregulation. Deregulation entails strategic diversion and disqualification of large numbers of would-be applicants who are left without alternatives to the labor market. In this article I discuss an empirical study of the effects of deregulation of welfare on the self-perceptions of recipients. Interviews with recipients and with low-wage health care workers, former recipients, show that, criticisms of welfare notwithstanding, they have embraced welfare reform's valorization of market labor; despite the women's continuing poverty. The interviews suggest that the "consent" of women in low-wage health care work is grounded in both powerlessness and resistance. Care taking, a role devalued by welfare reform, is valued by them and a foundation for identity and an imagined career.
\end{abstract}

*This is a revised version of a paper first presented at the annual meeting of the Law and Society Association, Las Vegas, Nevada, June 2005. The article discusses one aspect of an empirical research project examining the effects of welfare reform on recipients, former recipients, frontline workers, and administrators of welfare programs. Other aspects of the research are considered in earlier published and unpublished work, including, Frank Munger, Dependency by Law: Welfare and Identity in the Lives of Poor Women, in Lives IN THE LAw (Austin Sarat et al. eds., 2002); "Dependency by Law: The Policy Power of All Our Kin" a paper presented at the annual meeting of the Society for North American Anthropologists, Merida, Mexico, May 2005. I would like to thank Courtney Fennimore, Melinda Feng, Asha Smith, and Susan Liu, my research assistants, who not only brought energy, diligence, and intelligence to the work of the project but also offered thoughtful and valuable insights about its substance, for which I am deeply grateful.

**Professor of Law, New York Law School; Ph.D. (Sociology) 1997, J.D. 1968, University of Michigan. 


\section{Introduction: Welfare and Work in Buffalo, NEW YORK, 1997-2003}

Privatization is the symbolic core of the so-called "new governance." As a symbol of welfare state reform, privatization feeds on dissatisfaction with government, encouraged and exploited by politicians whose idealization of private sector efficiency and accountability is often at odds with daily headlines and our personal experience. Social citizenship is a concept that works in the opposite direction-protecting citizens from the ravages of the labor market and serving communal and collective values related to economic security, equal opportunity, and the development of individual capabilities.

In this article, I use focus-group interviews conducted over a number of years in Buffalo, New York' to explore possible answers to the following question: How have privatization of the welfare state and the discursive strategies of reformers affected self-perceptions of needy individuals and their social citizenship? In particular, how has privatization of welfare-a term now associated almost exclusively with poverty relief for poor women with children-influenced the construction of poor women's identities, and in turn, how have their identities, so influenced, affected the meaning of privatization for them and for all of us? I have not answered these questions in full, but with the help of participants in these focus groups, I have begun to explore answers.

By raising questions about the influence of welfare privatization on poor women I am also suggesting that there is a much larger field for research about the evolving social citizenship of the low-wage workers who fuel the American economy. How does the discourse of contemporary governance that advocates shrinking the welfare state influence their self-perceptions, aspirations, and capacity for political participation? Shrinking the welfare state is an action that is hostile to the well-being of low-wage workers and their families, yet they offer minimal resistance. ${ }^{2}$

In Parts II, III, and IV of this article, I will provide a background by defining and exploring the "new governance" paradigm, social citizenship, and welfare privatization respectively. In the latter parts of the article, I will address how

1. See generally Frank Munger, Dependency by Law: Welfare and Identity in the Lives of Poor Women, in Lives in THE Law (Austin Sarat et al. eds., 2002) (explaining the methodology of focusgroup interviews).

2. See Frank W. Munger, Social Citizen as "Guest Worker": A Comment on Identities of Immigrants and the Working Poor, 49 N.Y.L. ScH. L. Rev. 665, 667 (2004). 
poor, working women's sense of social citizenship is affected by the privatization and deregulation of welfare, through case studies from focus-group interviews. Finally, I conclude by addressing the implications of these effects on women's identities and on welfare policymaking more generally. This study of welfare law, identity, and citizenship draws on the growing field of theory and empirical research on legal consciousness. A central issue in research on legal consciousness is how the law becomes active through its mutually constitutive role in social relationships and individual identities.

\section{Privatization and the "New Governance" Paradigm}

Privatization is a powerful symbol of governmental reform and an important welfare-reform mandate. The sweeping 1996 federal welfare-reform law devolved responsibility for achieving work engagement, self-sufficiency, illegitimacy reduction, marriage, and responsible parenting to state programs. ${ }^{3}$ Under this law, the federal government provides block grant funding, ${ }^{+}$establishing minimum percentages of recipients who must be engaged in work, among other requirements, ${ }^{5}$ but leaving the structure and administration of welfare programs largely to state discretion; only a narrow supervisory role is reserved for federal administrators. ${ }^{6}$ The new law expressly encourages privatization by authorizing states to innovate by means including contracting out services to private providers. $^{\top}$ Welfare reform embodies, as much as any recent federal legislation, the decades-long ideological struggles over devolution to the state and privatization of government services. Welfare reform has inscribed private values on the relationship between the state and poor women in other important ways as well. ${ }^{8}$ Reform

3. This portion of the Personal Responsibility and Work Opportunity Reconciliation Act of 1996 is titled Block Grants to States for Temporary Assistance for Needy Families. 42 U.S.C. $\S \S$ $601-619$ (2000).

4. See 42 U.S.C. $\$ 603(a)(1)(2000)$.

5. See 42 U.S.C. $\$ 607$ (2000). Other requirements include time limits, mandatory school for minor recipients with children, and adult supervision for recipients under 18. 42 U.S.C. $\S$ 608(a)(4), (5), (7) (2000).

6. See generally 42 U.S.C. $\$ 602(2000)$.

7. See 42 U.S.C. $\$ 604(a)(2000)$.

8. See generally Michele Estrin Gilman, Legal Accountability in an Era of Privatized Welfare, 89 CAL. L. Rev. 569 (2001) (discussing the implications of welfare privatization on welfare beneficiaries' procedural rights). For a discussion on the general trend toward privatization, see Lester $M$. 
has transformed the goals of welfare. Behavior modification-by punishing nonwork and illegitimacy, while incentivizing marriage and the supervision of children-erodes barriers between public policy and the most private and intimate areas of life. As I will explain in a moment, contracting out welfare services and, in some states, transferring even the gate-keeping role of front-line eligibility workers to private-sector employees, is only one form of welfare privatization, and perhaps not the most significant one.

Remarkably, we have few studies of the implementation of welfare privatization. ${ }^{9}$ Further, there has been relatively little public comment on privatization

Salamon, The New Governance and the Tools of Public Action: An Introduction, 28 FordHam URB. L.J. 1611 (2001); Robin Cheryl Miller, Privatization of Governmental Services by State or Local Goveinmental Agency, 65 A.L.R. 5th 1 (1999).

9. Voluminous commentary on privatization belies the paucity of research on privatization's effects. See Gilman, supra note 8; Mathematica Policy Research, Inc., Privatization of Welfare Services: A Review of the Literature (2002); Martha Minow, Partners, Not Rivals: Privatization and the Public Good (2002); M. Bryna Sanger, The Welfare Marketplace: Privatization and Welfare Reform (2003), for helpful introductions. Privatization is typically equated with contracting out government services to private-sector providers. As I explain, this characterization of privatization is far too narrow to capture the range of transformative policies and their effects. See infra note 28 and accompanying text; Jon Michaels, Deforming Welfare: How the Dominant Narratives of Devolution and Privatization Subverted Federal Welfare Reform, 34 SETon HaLL L. Rev. 573 (2004) (comparing the effects of disentitlement and privatization). Legal scholars are often formalist in the sense that they focus on privatization's relationship to accountability. See, e.g., Jody Freeman, The Private Role in Public Governance, 75 N.Y.U. L. Rev. 543 (2000). Few legal scholars study the actual effects of privatization on particular agencies, services, or interactions with beneficiaries. They rarely report the point of view of those affected most by welfare privatization, namely current or former welfare recipients. Scholars in other disciplines have focused on the experiences of recipients but lack perspective on the way that law constitutes everyday experience and, ultimately, institutional change. See, e.g., Deborah L. Little, Independent Workers, Dependable Mothers: Discourse, Resistance and AFDC Workfare Programs, 6 Social Politics 161 (1999); Sondra Youdelman \& Paul Getsos, The Revolvinc Door: Research Findings on NYC's Employment Services and Placement System and its Effectiveness in Moving People from Welfare to Work (2005), available at http://www.cvhaction.org/english/reports/ The\%20Revolving\%20Door\%20-\%20Executive\%20Summary.pdf; Mimi Abramovitz, IN Jeopardy: The Impact of Welfare Reform on Nonprofit Human Service Agencies in New York CIty (2002), available at http://www.unitedwaynyc.org/pdf/in_jeopardy.pdf. Professor Edward Rubin, from Boalt Hall School of Law, notes that law and economics and critical law and society research have blazed a productive trail toward microanalysis of governance by combining empirical study of change at the grass roots with sophisticated a wareness of law's capacity to influence individual perceptions and, ultimately, institutions. Edward L. Rubin, The New Legal Process, the Synthesis of Discourse, and the Microanalysis of Institutions, 109 Harv. L. Rev. 1393 (1996); see also Edward L. Rubin, Beyond Camelot: Rethinkinc Politics and Law for the Modern State (2005). 
in comparison with media coverage of the reduction in welfare rolls. As coverage of the impact of the new law has all but disappeared, the 1996 welfarereform law seems to have brought closure to the deep public controversy. Members of the public, reassured by reports of steep declines in numbers of welfare recipients, may have assumed that the war against dependency is over.

"New governance" scholarship grows from dissatisfaction with formal legal models of administrative structure and accountability. ${ }^{10}$ Professor Jody Freeman uses privatization as a prime example of "new governance." "She and other scholars argue that the traditional modernist theory of "vertical" accountability to an electorate and between legislature and administrator is empirically false. ${ }^{12}$ Government decisionmaking is constrained largely through complex "horizontal" interactions between public officials and private citizens that take many different forms - formal, informal, discursive, or cognitive. Some of these forms have become formalized through modifications of rulemaking and other regulatory processes, but multifaceted, overlapping interaction embeds administrative decisionmaking in a network of relationships that constitute the real accountability, the real legitimacy. Thus, privatization-the quintessential horizontal relationship between public and private-is not a departure from historic patterns of governance, but at most an extension of the deep interdependence of public and private. Privatization, Freeman argues, need not reduce the effectiveness of public

10. The term "new governance" has been adopted by influential policy scholar Lester Salamon to replace phrases such as "reinventing government" that arose largely from politically expedient efforts to reduce unpopular tax and paperwork burdens. See Lester M. Salamon, The Tools of Government: A Guide to the New Governance 8 (2002).

11. See Freeman, supra note 9.

12. As Freeman argues,

Most administrative law theory now adheres to a hierarchical, agency-centered conception of administrative power in which the most pressing theoretical goal is to constrain agency discretion. Given the reality of public/private interdependence, I propose an alternative conception of administration as a set of negotiated relationships. Specifically, public and private actors negotiate over policy making, implementation, and enforcement. This evokes a decentralized image of decision making, one that depends on combinations of public and private actors linked by implicit or explicit agreements. One might describe this conception by using the term 'shared governance,' but 'governance' implies a hierarchy of control in which there is one thing-or a set of things-to be governed, and a center of control that does the governing. In my conception, however, there are only problems to confront and decisions to make. There is nothing to govern.

Freeman, supra note 9, at 547-48; accord Rubin, supra note 9. 
norms, but simply requires new, contract-like techniques. ${ }^{13}$ Freeman and others have been influenced by policy theorist Lester Salamon, who rejects what he considers an unproductive fixation on privatization, advocating instead a focus on the utility of a broad range of "tools of governance."1+

But Salamon ignores the powerful symbolism of privatization that influences the discourse and practice of governance. Privatization is not so much a specific tool as a value-a rejection of public norms in favor of interests that are not collective.

Privatization, as a value, is embedded in welfare reform. My point thus far is that privatization is symbolic-a metaphor for the shrinking domain of public values, especially those that sustain social citizenship.

\section{Social Citizenship}

Social citizenship is defined by the protections a society provides against the ravages of the market-the labor market in particular. ${ }^{15}$ The meaning of social citizenship in the United States can be gauged best by the fortunes of those who need it most-workers marginalized by the labor market and a competitive capitalist economy. This group is growing. Just under 25 percent of the labor force earned less than poverty-level wages in $2003,{ }^{16}$ or less than $\$ 18,810$ per year for a family of four if they worked full-time, year-round. ${ }^{17}$ Wal-Mart is the world's largest corporation, and its average wage is about $\$ 17,000$ per year. ${ }^{18}$ Wal-Mart offers health benefits to fewer than half its employees, and more than 40 percent of its employees leave each year. ${ }^{19}$ Figures on the inadequate wages for low-wage workers do not include the economic situation of those who have given up look-

13. See generally Freeman, supra note 9 (proposing a conception of governance as a set of negotiated relationships between public and private actors); Minow, supra note 9 (providing a somewhat darker assessment of the effects of privatization).

14. See Salamon, supra note 10, at 8-9.

15. See genetally Michael B. Katz, The Price of Citizenship: Redefining the American Welfare State (2001) (discussing the meaning of social citizenship).

16. Specifically, the percentage was $24.3 \%$, up from $23.1 \%$ in 2002 . Lawrence Mishel et al., The State of Working America 2004/2005 tbls. 2.11-2.13 (2005), available at http://www. epinet.org/datazone/05/poverty_wages.pdf.

17. See U.S. Census Bureau, Historical Poverty Tables tbl. 1 (2004), available at http:// www.census.gov/hhes/www/poverty/histpov/hstpov l.html.

18. Paul Krugman, Op-Ed., Always Low Wages. Always, N.Y. Times, May 13, 2005, at A23.

19. Id. 
ing for work. Those who are termed "unattached to the labor force" often live in the twilight of labor statistics-minority ghettos, deep poverty, and chronic unemployment. ${ }^{20}$

The discourse of social citizenship in 2005 is far to the right of the discourse of forty, or even twenty, years ago. Employment is the centerpiece of 1990s welfare reform in the United States. The new discourse of welfare is about work rather than poverty. Work is now the safety net. Work is the new welfare.

The range of this discourse is captured in the books on welfare reform by two writers lionized respectively by welfare reformers and their critics: New York University political science professor Lawrence Mead and Pulitzer Prizewinning journalist Jason DeParle.

In a recent study of welfare reform in Wisconsin, Professor Mead praises good governance by Wisconsin reformers who reduced Wisconsin's welfare rolls by 90 percent.." Drawing parallels between welfare-to-work, "brokenwindows" policing, more discipline in schools, and other examples of paternalism, Mead identifies norm enforcement authorized by the rise of a new moralism in administration as the heart of good governance. ${ }^{22}$

Mead views welfare privatization as a creative method of reforming governmental agencies that had become set in their ways and unable to implement the paternalism required to reform welfare recipients' conduct. Wisconsin heavily privatized its welfare administration in parts of the state it considered problematic (i.e., Milwaukee, where the principal minority population and most welfare recipients resided). Private contractors were responsible for administering a complex welfare-to-work program that required making judgments about work readiness, placing clients accordingly, and providing them with appropriate support. The contractors could keep a portion of whatever they did not spend on recipients. Mead acknowledges the disastrous consequences of privatization when private contractors failed to deliver. However, because the moral

20. See generally Comm'n on Behavioral \& Soc. Scis. \& Educ., Nat'l Research Council, Losing Generations: Adolescents in High-Risk Settings (1993) (discussing the profound influence that settings have on the behavior and development of adolescents); Copinc with Poverty: The Social Contexts of Neichborhood, Work, and Family in the African-American CommuNity (Sheldon Danziger \& Ann Chih Lin eds., 2000) (including various articles discussing poverty among African-Americans); Adrian Nicole LeBlanc, Random Fa

ily: Love, Drugs, Trouble, and Coming of Age in the Bronx (2003) (discussing examples of class injustice experienced by individuals in the Bronx); Carol B. Stack, All Our Kin: Strategies for Survival in a Black Community (1974) (discussing the plight of various AfricanAmerican communities).

21. Lawrence M. Mead, Government Matters: Welfare Reform in Wisconsin 142 (2004). 
goal of welfare reform is work, not ending poverty, no truly public norms were violated by the corruption or incompetence of private contractors. ${ }^{23}$ In a sense, these problems merely accelerated the desired outcome, and as Mead happily reports, Wisconsin's recipients left the rolls and few have complained. ${ }^{24}$

New York Times syndicated columnist and Pulitzer Prize-winner Jason DeParle offers a different assessment of Wisconsin's welfare-reform experiment in a study of three poor women in Wisconsin affected by welfare reform. ${ }^{25}$ DeParle makes some amazingly superficial judgments, but in the end he gets it mostly right. Welfare does not determine the women's fate: Women have always combined work and welfare, so welfare's disappearance does not change much. When welfare is available, he suggests, the women would be foolish not to apply, and so they do. DeParle observes that the meager, contingent welfare assistance available to them has been far less important to their quality of life than welfare reformers suppose..$^{26}$

DeParle gives numerous examples of the weaknesses of privatized welfare administration in Wisconsin. I infer that Mead, in contrast, formed a close relationship with top administrators who never saw first hand the difficulties of ad22. As Mead explains,

The main line of the Wisconsin reform was the enactment and implementation of general work requirements. In large part, that process was impersonal. The demands were enforced across the board for the employable adults. Many people were simply driven off the rolls by the demands, or by diversion, and nobody paid them much heed.

But viewed closer up, the process often involved a good deal of individualized attention. Case managers helped recipients arrange the child care and other services they needed to work. They also followed up on clients to be sure they fulfilled their obligation, which was to work or participate in assigned programs. This administrative style, which I call paternalism, seems to have developed spontaneously in Wisconsin. It has become the state's main contribution to antipoverty policy, after its more noted policy innovations.

Id. at 157.

23. Id. at 141-49.

24. "Yet despite the confusion and the sharp fall in the rolls, there was little sign of hardship. AFDC recipients proved far more capable of coping without welfare than anyone imagined. Many simply disappeared. Observers speculated that many of them were already working 'off the books.' These patterns of declining rolls, climbing work levels, administrative errors, yet few apparent negative effects would be repeated with W-2." Id. at 134-35. Mead makes no mention of any attempt on the part of welfare administrators to track those who "simply disappeared."

25. See Jason DeParle, American Dream: Three Women, Ten Kids, and a Nation's Drive to END Welfare (2004).

26. Id. at 330 . 
ministration on the ground, and as a result he discounts or overlooks these difficulties. Joel Handler has questioned the capacity of "third way" (or active labor market) welfare programs like Wisconsin's to sustain effective support for the transition to low-wage work, ${ }^{27}$ and the Wisconsin experience with privately administered welfare does not provide a convincing counterexample.

The problem with the Wisconsin success story is that there is so little information about what happens in the longer term, after driving recipients from the rolls. DeParle reports the administrative chaos on the ground, but the more important implications of his book lie in the continuing prospect of limited opportunities for poor women. Their survival strategies have almost always included work with or without welfare, and the failure of reform to improve their quality of life and alleviate their poverty suggests a poor fit between public assistance and their needs. Thus, the most important questions raised by DeParle concern a different face of privatization-not the contracting out of welfare administration but rather the deregulation of welfare altogether.

\section{Welfare Privatization}

In a recent article, Professor Alfred Aman suggests that privatization of government in the modern era has taken at least three forms, all of which are found in welfare reform and supported by powerful, if misapplied, ideologies of market competition. ${ }^{28}$

First, Aman lists contracting for services. Contracting out some specialized welfare services such as job training and placement has become common. Wisconsin led the nation in putting the administration of entire welfare programs up for bid. ${ }^{29}$ Professor Jon Michaels offers an extensive critique of the reform rhetoric that conflated devolution, including contractual privatization with third-way paternalism, thereby undermining the goals of welfare reform which seemed to promise assistance in achieving self-sufficiency. ${ }^{30} \mathrm{I}$ will not discuss

27. Joel F. Handler, The "Third Way" or the Old Way?, 48 U. Kan. L. Rev. 765 (2000). Handler's evidence for this pattern extends beyond the U.S. experience to Europe. See Joel F. Hander, Social Citizenship and Workfare in the United States and Western Europe: The Paradox of InCLUSION (2004).

28. See Alfred C. Aman Jr., Privatization and the Democracy Problem in Globalization: Making Markets More Accountable Through Administrative Law, 28 Fordham URB. L.J. 1477 (2001).

29. MEAD, supra note 21 , at 132-33 (explaining the privatization of welfare administration in Wisconsin).

30. See Michaels, supra note 9. 
contractual privatization here although there is much to learn about the ways that the private administration of welfare programs may have influenced recipients and the future of welfare. The empirical evaluations of such experiments are mixed. ${ }^{31}$ A strong foundation of Progressive Era social work values existed in the not-for-profit world, ${ }^{32}$ but that has all but disappeared as a result of public contracts that typically create financial incentives for bottom-line work engagement within a fixed period of time (goals mandated in turn by the federal block grant funding formula) rather than on long-term well-being. ${ }^{33}$ Evaluation of the New Hope experiment in Wisconsin suggests that some forms of intervention matter a great deal when they occur in the context of a voluntary, flexible, generous, and outcome-oriented private program. ${ }^{34}$ Interviewees from my groups sometimes said they benefited greatly from having a caseworker they could deal with who would provide counseling and greater latitude in using resources.

The second form of privatization identified by Professor Aman is use of the market to allocate a limited governmental benefit, for example, in the context of environmental regulation, emissions trading. Analogously, welfare reformers employed a strategy of regulation through work participation rates and block grant funding that gave states a great deal of discretion about allocating exemptions from work requirements but limited the overall proportion of the caseload that could be exempted. ${ }^{35}$ This faux market in allocating welfare assumes that lower-level decisionmaking is similar to ideal market allocation in that it is efficient and responsive to "consumer" preferences and needs. The false assumptions here are easy to spot. As always, states manipulate the system of federal funding to maximize their own return. Mead reports that the private contractors in Milwaukee at first exempted so many recipients that they jeopardized the state work participation rate, which is determined by the percentage of welfare recipients engaged in work. Worried about this threat to federal funding, a high-ranking Wisconsin administrator ordered the contractors to sanction more

31. See Mathematica Policy Research, supra note 9; Sancer, supra note 9.

32. See Martha Minow, Making All the Difference: Inclusion, Exclusion, and American LAw 239-66 (1990) (explaining the history and values of Progressivism); William H. Simon, Legality, Bureaucracy, and Class in the Welfare System, 92 Y ALE L.J. 1198 (1983).

33. See Sanger, supra note 9; Abramovitz, supra note 9.

34. See Aletha C. Huston et al., Manpower Demonstration Research Corp., New Hope for Families and Children: Five-Year Results of a Procram to Reduce Poverty and Reform WeLFARE (June 2003), available at www.mdrc.org/publications/345/full.pdf.

35. See 42 U.S.C. $\$ 607$ (2000). 
recipients for nonwork. Thus, unrelated to any change in recipient behavior, the rate of sanctioning rose from single-digit percentages to more than 30 percent in a matter of weeks, knocking many nonworking recipients off the rolls and restoring the participation rate. ${ }^{36}$

Recipients manipulate the allocation system as well, by "banking" their time. But this means, of course, that they forego assistance that might have made a critical difference to family well-being. Reformers' prejudgment that reliance on welfare is an irresistible moral hazard is not really based on consumer preferences at all.

Third, Professor Aman points to deregulation, such as the deregulation of the airlines in the United States. Although this form of privatization appears most radical and complete, there are always hidden public costs to deregulation when the newly created market does not perform correctly or fails to accommodate the needs of all stakeholders. Costly government intervention often follows to clean up the mess. Deregulation was the welfare reformers' most important goal. Their principal aim has been to get recipients not into work but rather off the rolls. When the five-year time limit runs, federally funded welfare ends, and in many states the time period is considerably shorter. ${ }^{37}$

For former welfare recipients who find work, an irony of deregulation is that it is largely one-sided. While former welfare recipients, indeed low-wage workers in all categories, face increasing deregulation of the labor market, the dependency of their employers on the public is increasing. Enron's exit strategy transferred billions in defaulted pension benefits to public trust funds. WalMart pays health benefits for less than half its workers, and among the most important public costs of Wal-Mart's entry into a market is the rising use of public health facilities and insurance programs by their employees. ${ }^{38}$

Of course, deregulation of welfare has achieved the goals of the most radical welfare reformers far more effectively than the other forms of privatization. The reasons for its success have been much debated-both the strong economy of the late 1990s and the push of paternalistic welfare policies have played a part.

36. Mead, supra note 21 , at 146.

37. 42 U.S.C. $\$ 608(a)(7)(2000)$. In a few states, state law requires some form of continuing assistance, although it need not be cash assistance, and work requirements may continue. In New York, for example, a state constitutional provision requires some form of continuing assistance to relieve poverty after federally funded welfare has been terminated. See, e.g., N.Y. Const. art. XVII, § 1 .

38. Krugman, supra note 18. 
One possible, if surprising, reason for departures from the rolls, notwithstanding continuing poverty, is that many recipients actually embrace the concept of privatized dependency that legitimizes punitive supervision, withdrawal of benefits, and continuing poverty. This is the other face of the new "benign neglect." Recipients have always had a double consciousness of welfare-knowing their need but embracing mainstream criticism of nonwork and dependency. Now their self-deprecation is being reinforced by increased stigmatization of welfare dependency and the celebration of work.

As we know, for most former welfare recipients there is little economic gain from low-wage work. ${ }^{39}$ Their work is poorly paid, unstable, and without benefits, and most employers are unaccommodating for family care or personal health needs. ${ }^{40}$ Welfare reformers equated dependency with receiving public welfare, but welfare's deregulation returns the former recipient to another form of dependency - working dependency that often fails to raise a family's quality of life or increase the family's opportunities for betterment. Yet many recipients accept low-wage work as a morally worthy alternative to welfare. ${ }^{41}$

Welfare deregulation has an ideological framework. Welfare deregulation presumes, following Mead's influential analysis of previous federal welfare programs, ${ }^{42}$ that lack of motivation to work is the primary cause of poverty. In this view, material resources-income, adequate schools, decent and stable housing, safe neighborhoods, and medical care-are important, but secondary. Deregulation of welfare aims to place responsibility for as much of this material support

39. See generally Pamela Loprest, How Are Families That Left Welfare Doing?: A Comparison of Early and Recent Welfare Leavers, New Federalism (Urban Inst., Washington, D.C.), Apr. 2001 [hereinafter Loprest, Families That Left Welfare], available at http//www.urban.org/uploadedPDF/ anf_b36.pdf (describing the economic barriers to leaving the welfare system); Pamela Loprest, Fewer Welfare Leavers Employed in Weak Economy, SNapshots III (Urban Inst., Washington, D.C.), Aug. 2003, available at http://www.urban.org/uploadedPDF/310837_snapshots3_no5.pdf (describing the poor employment prospects for welfare leavers). About $4 \%$ were surviving on other government programs such as SSI, and $7.6 \%$ had a working family member who supported them. See id. fig.l. More than $20 \%$ had no current source of income (although about one-third of these had worked recently). Id.

40. See Loprest, Families That Left Welfare, supra note 39, at 3-4.

41. Conversely, as I discuss elsewhere, women receiving welfare sometimes view their reliance on welfare, single motherhood, and lack of work in exactly these terms, as a mark of failure, even though we might identify many factors that have created barriers to self-sufficiency that lie outside their control. See generally Munger, supra note 1.

42. See Lawrence M. Mead, The New Politics of Poverty: The Nonworking Poor in America (1992). 
as possible outside the welfare system, and, as Mead has forthrightly acknowledged, this is deeply problematic.

The question I want to consider is how a working poor woman's sense of her social citizenship has been affected by welfare deregulation.

\section{Working Poor and Welfare Client Stories}

Over the past eight years I have conducted three sets of focus groups in Buffalo, New York: with residents of Buffalo's poorest housing project, with former welfare recipients who were working as certified nurse's assistants or licensed practical nurses, and with a cross-section of unemployed men and women (interviewed separately). These interviews provide a window on the successes and failures of welfare reform and its emphasis on privatization in all of the meanings that I have described.

My interviews with poor women in the lowest-paid health care jobs are particularly revealing. The women are poster children for welfare reform because they have left public assistance behind them, they support themselves and their families through work, and, above all, they embrace the promise that a job can lead to a career and a better life for themselves and their families. I am interested in, among other things, how these women have been affected by the discourse of privatization. Further, their understanding of their social citizenship, and whether it has been influenced by the transformation of entitlements and public morality, is an important example of legal consciousness.

In an empirical study of the effects of the Americans with Disabilities Act, ${ }^{43}$ life-story interviews with sixty people with disabilities revealed four ways that the law became active in the lives of the interviewees. They are equally relevant here: (1) formal implementation through public or private enforcement-none of our interviewees actually invoked the law in this way, (2) institutional change not initiated by our interviewees, (3) the law's influence on society's discourses about disability and rights, and (4) the law's influence on identity.

The last is particularly important and often overlooked. Law, we discovered, is a constitutive element of any social context. Law is given meaning by those who perceive and act with reference to law's authority, but this does not mean that they follow the law. First, there is the question of what "following the law" means; the

43. David M. Encel \& Frank W. Munger, Rights of Inclusion: Law and Identity in the Life Stories of Americans with Disabilities (2003). 
law, like other cultural artifacts, is constructed. Second, as contemporary law and society studies show, the law may be apprehended in different ways depending on how one perceives oneself in relation to law. For example, perception of oneself as welfare dependent, guilty of welfare fraud, or part of the mainstream who does not require welfare-self-perceptions expressed by different women who were in very nearly identical circumstances-may lead to a different discourse about law and its meaning. As a consequence, both the law's meaning and the meaning law gives to individual identities can shift and change. Law may become active in different ways throughout a life story and, in turn, may have varying repercussions on the individual's sense of self.

I will offer brief examples from two of my focus-group studies.

\section{The Perry Project - The Poorest of the Poor}

When I interviewed Perry Housing Project residents in 1997, they were praying for Buffalo to deliver on its long-standing promise to raze the project's dilapidated buildings. It is Buffalo's black project, and it is geographically isolated. The community is a Gulag created by public policy. The law's oppression is apparent here: Public issues of safety, welfare, and housing dominate the women's lives. The power of law in private relations is also apparent-there are few stores and thus few choices as a consumer. There is no access to credit on fair terms. There is no transportation and no nearby employment opportunities.

\section{A. Sarah Cox}

No narrative is "typical," but many of Sarah Cox's experiences were similar to those of other members of the Perry Project focus groups. As a teen and single mother of one child, Sarah worked at a low-wage job in a frozen-food packing plant until she injured her leg, making it difficult to stand. A bus picked Sarah and her co-workers up on a corner each morning, and they returned home only when the bus was ready to bring them back. The plant was cold and damp, and on one occasion, too sick to continue work, she sat on the unheated bus for most of the day until it was ready to return. Sarah became involved with a drug-addicted boyfriend and had a second child. She made a poor choice in her relationship-but she had few to choose among. A shocking proportion of the women I spoke with in the Project were limited by their poor health, lack of education, and a family and friendship network that had little experience with a different life outside 
Buffalo's black ghetto. ${ }^{\text {t4 }}$ Ultimately, Sarah's sister took her children, and the Department of Social Services provided support that allowed Sarah to rid herself of her drug habit. She has recovered her children, but due to her injury and lack of education, she has little prospect of living-wage employment.

\section{B. Sarah's Identity and the Law}

Many of the women in the Perry Project focus groups expressed a sense of failure. "I fell," says one. The strict Pentecostal upbringing is apparent, but welfare's message seamlessly reinforces this identity. The law provides an uncertain perimeter of security - the boundary between the safe space within the apartment and the danger without. Neither the housing authorities nor the police are trustworthy, and security must constantly be negotiated.

Yet Sarah viewed welfare favorably_-a source of help when she was desperate. Its paternalism is not her concern. Rather, welfare was a lifeline when she did not have enough strength or social capital to cope. She is strong; she is not passive. But she was destitute and perceived herself as having limited capacity for self-help. She is now grateful for welfare, which provided support when low-wage work was insufficient and she lacked the social capital to make it on her own, let alone thrive. She believes in inclusion, and she perceives welfare in terms of the reciprocity that she has learned to trust in the way anthropologist Carol Stack describes the formation of social capital of the ghetto. ${ }^{45}$ As a taxpayer herself, Sarah would not object to supporting those in need:

Everybody needs help and there's [sic] not like they're taking a lot away from you to help keep social service going to benefit others. So I wouldn't feel that way. I just would always say, "Well, if I'm workin' and I can, maybe eventually somewhere down the line they'll go to work, and they'll give back what was given to them."

44. For a discussion of the limitations caused by social capital among poor minority women, see Stack, supra note 20; Coping with Poverty, supra, note 20.

45. STACK, supra note 20. 


\section{The Buffalo Employment Training Center and the Meaning of a Career}

A few years later, I conducted focus groups with poor women attempting to create a career in health care service work-as a home health aide, a certified nurse's assistant, or a licensed practical nurse. They received financial support and counseling through the Buffalo Employment Training Center (BETC), which was where I met them.

With small changes in fortune, these women also could have been Perry Project residents. They had barely enough resources to free themselves from the reciprocal demands of family and friends to earn a license to empty bed pans.

They were lucky to be in Buffalo at a time when most of the country considered itself lucky not to be there. In the early 1980s, a billboard read, "Would the last worker to leave Buffalo please turn off the lights." Low-wage health care jobs were available in Buffalo in abundance in the many hospitals, medical centers, and nursing homes. Indeed, the oversupply of hospital beds may threaten job stability, but that was not an immediate concern of these women.

Health care has come to represent a career in the minds of many poor women. As one women explained to me, you could begin as a Home Health Aide (HHA), later become qualified as a Certified Nurse's Assistant (CNA), and, after a year-long program, a Licensed Practical Nurse (LPN). The imagined path led onward to becoming a registered nurse, a surgical assistant, a doctor, or even a Ph.D. All it took was hard work, a little luck, and a great deal of prayer.

The reality of health care "careers" is quite different. Work done by HHAs, CNAs, and LPNs is similar. They do the primary hands-on care for patients, and in addition, LPNs can handle prescription medicines. They empty bed pans, bathe the patients, dress them, brush their teeth (or put them in), comb their hair, turn the patient monitors on or off, move the patients around, sit them up to greet relatives, and-though not an assigned task-provide their patients with whatever emotional support it is in their hearts to do.

The pay is extremely low, and they have little real skill. Health care has become a profitable industry. ${ }^{46}$ While health care workers are in demand, the work is lousy, and the employees are often treated badly. They are interchangeable

46. Timothy Diamond, Making Gray Gold: Narratives of Nursinc Home Care (1992). 
parts. Yet they are hopeful. Why does health care hold such an attraction? They may be better off than some low-wage workers because they are in demand. ${ }^{+7}$

More revealingly, many say they chose health care because it offered work that matched an identity they embraced. It is a respectable profession; the workers may use the caretaker knowledge many have developed as parents and heads of households, offering prospects for higher income, and a route to selfimprovement. Their experiences could help them construct a different picture, but this is the career that they want.

\section{A. Ellen Watson and Betty Martins}

Ellen and Betty are savvy LPNs with long work histories. They have always been poor, yet they aspire to much higher achievement-completing college and moving to a middle-class profession. Their chances are slim, yet they have achieved a great deal with the meager support that public programs offer. They had working parents, although the households were often unstable. They completed more education-typically some years beyond high school. They had fewer problems with domestic violence, drug abuse, and abandonment than those unable to complete the LPN program seem to have faced.

Their views of the law are pragmatic. They have been helped in the past by welfare. They have not received welfare for many years, although Betty participates in the federal Section 8 subsidized-housing program and is on a waiting list for an affordable housing purchase. ${ }^{48}$ They are "with the law" when it has benefited them. ${ }^{49}$ They are of an altogether different mind when the law is paternalistic and limiting. Betty is manipulating the Section 8 law by limiting her hours of work carefully to remain eligible for this low-income housing program. And she will never apply for welfare again because, under the current law, a lien would be placed on her house to guarantee repayment.

47. The Bureau of Labor Statistics ranks home health services and other low-skill health care jobs among the fastest-growing occupations in America. See U.S. Bureau of Labor Statistics, Industry Employment, Occupational Outlook Quarterly, Winter 2005-2006, at 30, 36, available at http://www.bls.gov/opub/ooq/2005/winter/art03.pdf.

48. See National Housing Act $\$ 8,12$ U.S.C. $\$ 1701$ s (2000).

49. In an influential study of legal consciousness, in-depth interviews about conflict and law suggest that a number of discourses about legality seem to be widely shared. A discourse of acting "with the law" emerges when rights are deployed to an individual's advantage. Other discourses, "before the law" and "against the law," emerge in other paradigmatic circumstances. Patricia Ewick \& Susan S. Silbey, The Common Place of Law: Stories from Everyday Life (1998). 
Q: How were you treated?

Betty: Real terrible. They do not want you to succeed. They don't want you to do anything more than what they want you to do. Like when I was, before I was on CAP la prereform New York welfare program no longer in existencel and I worked ... and I was getting a certain amount of money, but I went a couple of dollars over or something, and they took so much money. You know, they just expect me to survive on what they give you. You know, and it's not right to be on social services I guess to say, if that's what you have to do. But if the resources are there to do something else, and you want more, social services is not the answer. It's really not. 'Cause they don't want you to have a car, they don't want you to have a house, they don't want your car to be of a certain amount, it has to barely be able to go from corner to corner. You know, they just, add everything up, you know, you have nothing, nothing.

Ellen: They just want to build you up and knock you down.

\section{B. Latanya Smith}

On a separate occasion, I spoke with a BETC client who failed to complete her LPN program. Like many other prospective LPNs, she has worked for many years as a CNA. Latanya derived important lessons from her childhood, growing up in a household supported in part by welfare and troubled not only by poverty, but also by sexual molestation (an uncle) and by drug abuse (her mother). Latanya is the oldest of four children. She was more responsible than her siblings, but also more rebellious. Her early life included periods of foster care and placement in supervised living centers, as well as social work support. But she was purposeful, lucky, and, ultimately, a survivor. At age twenty-three, she describes an important lesson that has guided her struggle for an education and a career in health care.

Q: You have said that you don't want to be on welfare, and said it with some force. So you have some feeling that folks look at people on welfare in a different way? 
Latanya: In a way... Maybe I feel that way because ... I don't want it ... I think welfare is bad. Now, I don't think it's all bad. Some people really need it. But ... it's people's perceptions $\mid$ of $\rceil$ my skin tone.... And you know, it's sad to say. There's, there's [sic] a lot of people that make it look bad for people who are really trying to do something but still need those services. I don't support girls who just lay around having babies and expect to receive food stamps. I would support someone who is in the same position like me, either working and going to school and just somehow just can't afford it or they were already just having kids and they're trying to get their life together now and they still need those services. But a lot of people don't see it that way. I don't want to be judged by that.

Ellen, Barbara, and Latanya, three women in low-wage health care work, are well aware of the law's contradictions. For them, this feature of welfare law-its hostility to the poor and its misperception of their character-is central to their legal consciousness. They do not perceive themselves as stereotypical welfare recipients, yet they are aware of the stereotype. It reinforces their identities as women who do not receive, and do not want to receive, welfare. Their present social positions in private employment provide a foundation for the identities they prefer, allowing them to distance their identities from welfare. Their success in distancing themselves from welfare is an important quality of a "career" in low-wage health care.

Even among women who are receiving welfare, there is a dual consciousness that welfare is necessary but that it corrupts their identities by stigmatizing them as dependent. They voice this dissonance by criticizing other women who, they say, abuse the system.

There is a third discourse that was not apparent among the Perry Project women, but was clearly voiced by Ellen and Betty, a discourse of critique and resistance to the meanness of welfare reform. The discourse of critique may be a form of backlash against welfare reform, even while former recipients embrace their identities as nonrecipients. The backlash would be an understandable response to reformers' explicit stereotyping and their highly publicized claims about the moral character of recipients. Welfare, and welfare administrators, have lost some of their authority over recipients whose situated identity has moved away from welfare and into private employment. 


\section{Conclusion: Privatization and Identity}

The stories of poor women suggest the law's authority is deeply embedded in their lives, but their stories also suggest that there is a difference between dependency on welfare and dependency constructed by welfare law. Most poor women are not weak, nor do they lack the will to protect and raise their families. ${ }^{50}$ They are not reluctant to work. They live under conditions created by institutions beyond their control. Although welfare is depicted as the state's beneficence, welfare is a form of control. Through welfare policy, recipients are closely supervised for compliance with family and work requirements shaped by the law's embodiment of a recipient's identity. The policymakers' misperceptions of poor, and especially black, women ensure that welfare is often still at odds with the women's preferences for child care, isolates women from their kindred, and most importantly, reinforces a stereotypical identity that influences every aspect of the women's lives. I have written elsewhere about these effects on women's identities. ${ }^{51}$

Here, I conclude by suggesting that the women also have meaningfully different perceptions of welfare law. For most poor women, welfare has never been about rights. As anthropologist Carol Stack found, poor women adapt to the absence of decent work, affordable housing, or the prospect of a stable marriage long before a challenge to the welfare state's treatment of them is ripe. ${ }^{52}$ Yet the stories they tell about themselves reveal a great deal about perceptions of law embedded in their adaptations to poverty.

An extraordinary postreform study of welfare privatization in New York by Professor Deborah Little ${ }^{53}$ describes interactions between recipients and caseworkers employed by a private organization under contract with New York City. She focuses on conflict between recipients' and caseworkers' perceptions of need-between the carework that dominates recipients' perceptions and the caseworkers' male-model perceptions of work, a model derived directly from welfare-reform discourse. An equally penetrating study of prereform welfare by

50. The research substantiating this point is voluminous. See, e.g., Kathryn Edin \& Laura Lein, Making Ends Meet: How Single Mothers Survive Welfare and Low-Wage Work (1997); Sharon Hays, Flat Broke with Children: Women in the Age of Welfare Reform (2003).

51. E.g., Munger, supra note 1.

52. STACK, supra note 20.

53. See Little, supra note 9. 
John Gilliom details the moral-psychological effects of intrusive supervision of recipients' lives that leaves them little privacy or room to maneuver to meet carework needs or values. ${ }^{5+}$ Intrusive supervision conflicts with need but resonates with moral responsibility and the authority of law. The supervision required by law ultimately makes the women delinquents in their own eyes for concealing information or breaking rules in the service of their own deeply held values concerning care and responsibility.

Both studies emphasize the effects of conflict between the symbolic and actual identities of welfare recipients. The symbolic identity of a welfare recipient-the identity that simultaneously legitimates benefits and supervision-is in conflict with the recipient's actual identity, her sense of herself. In each case, the conflict between the symbolic and actual identity has potentially serious negative consequences for recipients.

One might predict that women who perceive their identities much as reformers perceive them - needy and failing - may respond to the law's authority more passively, while women who perceive themselves as striving in the mainstream will be more strategic and active. Yet the interviews I conducted suggest that the relationship between law and the identity of many poor black women is more complex, often revealing a dual consciousness. Women's narratives contain elements of both accommodation and acquiescence on one hand and of resistance and alienation on the other. The self-critical narratives of Sarah Cox and her Perry Housing Project neighbors accepted the essential rightness of welfare's paternalism. Yet Sarah's view of welfare was sophisticated and complex. She viewed welfare as part of a larger societal contract of entitlement based on the presumption that everyone has the capacity to contribute and that everyone is at risk of dependence.

What happens when welfare is deregulated, when dependency is shifted from the public to the private sector?

For women in low-wage health care work, welfare has not been truly deregulated, as even conservative political scientist Lawrence Mead acknowledges. The low-wage sector does not provide sufficient welfare, and, indeed, it exploits the continuing eligibility of employees for public benefits, including state child care subsidies, publicly funded health care, federal and state wage supplements such as the Earned Income Tax Credit, and many other benefits.

54. John Gilliom, Overseers of the Poor: Surveillance, Resistance, and the Limits of Privacy (2001). 
The women's simultaneous dependency on public and private "welfare" places them in a liminal state between the identities associated with each. Ellen Martin acknowledges that she manipulates Section 8 benefits by keeping her hours of work just below the threshold for disqualification while earning enough to accumulate assets she needs for the purchase of a home. She does not have the option of presenting her needs in a forthright way to public officials. She is work ing less than she might - failing to perform as reformers expected. Her public dependency is calculated, as much as the rules of the program are calculated, to force her to behave according to a norm of self-sufficient social citizenship.

Latanya Smith refuses cash welfare because its symbolic cost is too great. She received food stamps while working as a medical receptionist half-time to permit school attendance. When her employer cut her time by a few hours, she no longer qualified for food stamps, but she could not bring herself to explain to her employer why she needed a few extra hours. As she explains (in the quote above), welfare is associated with "people of my skin tone," and she knows that the identity of all African-American women can be shaped by the negative stereotype of the welfare mother.

Latanya has been lucky. Her college-educated boyfriend earns enough to allow her to pursue her dream of becoming an $\mathrm{RN}$-something that few of the interviewees had the resources to do. Yet her knowledge of the private sector that she is navigating is limited by the absence of first-hand experience among her peers, family, or mentors. Indeed, she learned about CNA certification, BETC's LPN scholarship, and the community college RN program she will attend in the fall through local knowledge, acquired fortuitously, but which could just as easily have been missed had her luck been otherwise.

The law plays a different role in each of their narratives, and in turn, the law contributes to their identities as former welfare recipients in different ways. Ellen, Betty, and Latanya's narratives of law and identity seem particularly important because they are employed and doing what welfare reformers wanted. They have chosen low-wage work that seems to be the first step in a career. Of course, it is the lure of becoming an RN, not their satisfaction in emptying bed pans and cleaning incontinent and unresponsive nursing-home residents, that has powered their vision of a career. They do not need to rationalize the privations of a low-wage health care job as they might the oppressive conditions at McDonald's or a frozen-food packing plant.

Carework is the source of much that is satisfying and empowering in the lives of poor women. As Stack's anthropology shows us, the extended family 
unit - the unit she calls the "kindred," tied together by children and child care-creates social capital in the ghetto.

Thus, the symbolic power of health and personal carework derives from two sources, both ultimately reinforced by the filtering down of law to the private lives of poor women: Health care work is a legitimate career, and health care work makes a virtue of work within the kindred that was denigrated by the disciplines of welfare eligibility.

The poor women's hostility is directed disproportionately toward public welfare dependency and the public sector, rather than toward the oppressive conditions of their current employment, by the identity constructed to encompass both their aspirations for a career and their poorly paid health care work ${ }^{55}$

Useful knowledge that might be drawn from poor women's narratives is immediately apparent. The women who have been driven from welfare are not outside the moral mainstream; their dependency is a rhetorical construction, much as we construct the breadwinning male as independent, notwithstanding the family that takes care of many of his needs or the welfare state that augments his own efforts with employer tax incentives, mortgage interest deductions, and pension guarantees. The women strive, marry, and raise children as responsibly as they can with very little assistance, and they engage in strategic planning for a better life. Women who have left welfare are representative of a large proportion of former and present recipients whose poverty, not indolence, and absence of opportunities, not misbehavior, drove them to welfare.

Narratives of striving and accommodation show how institutions, not motives or resourcefulness, have failed these individuals. From this knowledge we might begin to envision alternatives. Professor Lynne Haney has chosen the term maneuverability to describe the consequence of transforming family support, educational opportunities, and work options so that individuals have meaningful choices and the freedom to choose among them. Haney studied the welfare for poor women under successive political regimes in Hungary. ${ }^{56}$ The government of socialist Hun-

55. Perhaps, without stretching the analogy too far, we might understand their consent to privatization on such wretched terms as having been "manufactured" by law, just as in Burawoy's classic study of shop workers, who became reconciled to their subordinate status in relations of production by being delegated limited authority to manage social relations on the shop floor. Michael Burawoy, Manufacturinc Consent: Changes in the Labor Process under Monopoly Capitalism (1979).

56. See Lynne Haney, Inventing the Needy: Gender and the Politics of Welfare in HunGaRY 242-44 (2002). 
gary intruded deeply into work, family, and all other areas of social life, ${ }^{57}$ creating opportunities for women to provoke the state to support their demands for flexibility and accommodation in each institutional sphere, permitring them to choose how to thrive. ${ }^{58}$ Under the liberal regime instituted after the fall of the socialist government, welfare was restricted, forcing women to make accommodations in the private sphere through family networks or the labor market. The net effects on women under the two regimes were dramatically different. Under the first regime, women gained the capacity to maneuver effectively in order to increase their welfare. Under the last regime, women's freedom to maneuver was severely limited by their lack of capacity, and families experienced far greater difficulties.

Maneuverability is promoted, Haney argues, when governments hold major institutions accountable for women's welfare rather than striving to fix or improve the women. ${ }^{59}$ Maneuverability is increased by the availability of flexible jobs, supportive work places, family resilience, housing options, continuing medical benefits, and retirement security. A core component of this goal is accommodation of flexible careers that include periods of carework and voluntary unemployment to pursue education or other forms of human capital growth without the destructive side effects that characterize liberal welfare regimesinsecurity and even destitution. Until we provide such opportunities, we will continue to find tales of heroic survival as well as moral failure in the narratives of poor women, stories which stir our emotions but document a struggle that is unlikely to lift many from their poverty.

Narratives of law, identity, and deregulation of welfare not only provide windows into the motives and actions of their protagonists, but they are themselves part of the process of constructing relationships among poor women and between poor women and authority. Narratives, a critical step in identity formation, explain who one is and where one ought to be in relationship to others, positioning the individual to assert or ignore rights. ${ }^{60}$ Professors Patricia Ewick and Susan Silbey's path-breaking exploration of "legal consciousness" describes the role of "subversive stories" that draw authority into question. ${ }^{61}$ Stories can be

57. See id. at 243.

58. See id. at 244.

59. See id. at 244-45.

60. ENGEL \& Muncer, supra note 43.

61. See Patricia Ewick \& Susan Silbey, Narrating Social Structure: Stories of Resistance to Legal Authority, 108 Aм. J. Soc. 1328, 1343 (2003), available at http:/www.journals.uchicago.edu/AJS/ journal/issues/v108n6/060013/060013.web.pdf. 
in themselves acts of resistance, but they may also invite resistance by others. Professor Francesca Polletta argues that stories-with their appeal to common experience, implicit moral message, and openness to interpretation-can be a powerful invitation to public discourse about policy. ${ }^{62}$ Thus, the reconstruction of welfare law in the narratives of poor women may offer a resource not only for them as they "navigate the welfare state from below" ${ }^{33}$ but also for others who attempt to steer the ship from positions of power that make policy.

62. Francesca Polletta, Freedom is an Endless Meeting: Democracy in American Social Movements (2002).

63. This imaginative description was used by Professor Michael Katz in personal correspondence with the author preceding a Russell Sage Foundation-funded workshop on low-wage labor held at SUNY Buffalo School of Law in 1997. Letter from Michael Katz, Professor of Economics, University of California-Berkeley, to Frank Munger, Professor of Law, New York Law School (Sept. 1997) (on file with author). 
